Dalam Pemilihan Umum 2014 (Studi Terhadap Pemuda Di Yayasan Pondok Pesantren Ali Maksum, Krapyak Kulon, Desa Panggungharjo, Kecamatan Sewon, Kabupaten Bantul, Daerah Istimewa Yogyakarta)

JURNAL KETAHANAN NASIONAL

\title{
KETAHANAN POLITIK WILAYAH PONDOK PESANTREN DALAM PEMILIHAN UMUM 2014 (Studi terhadap Pemuda di Yayasan Pondok Pesantren Ali Maksum, Krapyak Kulon, Desa Panggungharjo, Kecamatan Sewon, Kabupaten Bantul, Daerah Istimewa Yogyakarta)
}

\author{
Bagus Anwar Hidayatulloh \\ Fakultas Hukum Universitas Islam Darul Ulum (UNISDA) Lamongan \\ E-mail: bagusanwar.responsif@gmail.com \\ Sudjito \\ Fakultas Hukum Universitas Gadjah Mada \\ Agus Pramusinto \\ Fakultas ISIPOL Universitas Gadjah Mada
}

\begin{abstract}
Boarding school was a religious educational institution, had become a very important entity in the process of transmutation of values within the Republic of Indonesia, especially in the election. This research was qualitative descriptive exposure. The approach of research was the study on a problem that occured in a scope of society.

Collecting data in this study used observation, in-depth interviews, documentary studies and literature study, internet, plus a simple qualitative supporting data.

The results showed that the participation of youth in the 2014 election in Pondok Pesantren Ali Maksum positive implications (good) against political resilience of region of the boarding school. The implications of such forms of ductility and toughness of youth in response to the 2014 election, because it did not impact on apathy in contributing to the resilience aspect of the 2014 election in the form of resilience to the social and political consciousness, discipline and social dynamics of the region.
\end{abstract}

Keywords: Political Resilience of Region, Islamic Boarding School, General Election

\begin{abstract}
ABSTRAK
Pondok pesantren merupakan lembaga pendidikan agama, telah menjadi entitas yang sangat penting dalam proses transmutasi nilai-nilai dalam wilayah Republik Indonesia terutama dalam pemilu. Penelitian ini merupakan penelitian kualitatif dengan pemaparan secara deskriptif. Pendekatan penelitian yang digunakan adalah studi pada suatu permasalahan yang terjadi di suatu ruang lingkup masyarakat.

Pengumpulan data dalam penelitian ini menggunakan observasi, wawancara mendalam, studi dokumentasi dan studi kepustakaan, internet, ditambah data penunjang kualitatif sederhana.

Hasil penelitian menunjukkan bahwa Partisipasi pemuda dalam Pemilu 2014 di Pondok Pesantren Ali Maksum berimplikasi positif (baik) terhadap ketahanan politik wilayah pondok pesantren. Bentuk implikasi ini berupa
\end{abstract}


keuletan dan ketangguhan pemuda dalam menanggapi pemilu 2014, karena tidak berdampak pada apatisme dalam berkontribusi dalam pemilu 2014. Aspek ketahanan tersebut berupa ketahanan terhadap kesadaran sosial politik, disiplin wilayah dan dinamika sosial.

\section{Kata Kunci: Ketahanan Politik Wilayah, Pondok Pesantren, Pemilu}

\section{PENGANTAR}

Kajian pesantren yang merupakan lembaga pendidikan agama, telah menjadi entitas yang sangat penting dalam proses transmutasi nilai-nilai dalam wilayah Republik Indonesia (Ahmadi, 2010:1). Klasifikasi masyarakat dalam memilih partai bisa dibagi dalam dua kategori yaitu pemilih pemula yang bisa dikategorikan muda dan pemilih yang sudah merasakan berkali-kali pemilu. Penelitian ini meneliti tentang pemuda yang ada di pondok pesantren. Pesantren adalah sebuah dunia yang menarik untuk dikaji dan diteliti. Meskipun selama ini banyak peneliti menjadikan pesantren sebagai objek kajian, selalu saja tersedia perspektif tertentu yang belum bisa diungkap. Hal ini menunjukkan bahwa pesantren memiliki kekayaan khazanah pengetahuan sosial yang dapat diteliti dari berbagai aspek keilmuan. Posisi pesantren yang demikian menjadi bukti bahwa pesantren bukan hanya lembaga pendidikan Islam tertua di Indonesia dan masih tetap eksis hingga kini, tetapi juga merupakan entitas sosial yang memiliki pengaruh cukup kuat sekaligus unik dalam partisipatif politik di Indonesia (Ernas dan Ferry, 2010: 196).

Tempat yang diambil adalah lingkungan pondok pesantren tepatnya adalah Pondok Pesantren Ali Maksum Krapyak Yogyakarta. Pondok Pesantren Ali Maksum Krapyak merupakan lembaga pendidikan dan sosial keagamaan di bawah naungan Yayasan Ali Maksum Krapyak Yogyakarta. Didirikan pada tahun 1990, Yayasan Ali Maksum adalah badan hukum pelanjut amal usaha almarhum Kyai Haji Ali Maksum dalam kiprah perjuangan selama hidup beliau (Krapyak.org, 17 Agustus 2015). Pesantren Krapyak sering disambangi oleh para pejabat dan politisi di saat musim pemilu. Kemudian ditambah lagi, mantan Ketua Umum Partai Demokrat Anas Urbaningrum adalah menantu KH Atabik Ali, putra tokoh besar NU KH Ali Maksum (alm) dari Pondok Pesantren AlMunawwir, Krapyak, Yogyakarta. Pondok Pesantren Al-Munawwir, Krapyak adalah salah satu tonggak (pesantren) penting dalam perkembangan sejarah NU selain Tebu Ireng dan Tambak Beras di Jombang, Jawa Timur (inilah.com, 4 Maret 2015)

Setelah beberapa tahun mulai muncul yayasan baru dengan nama Yayasan Pondok Pesantren Ali Maksum dengan konsentrasi di Sekolah Menengah Pertama (SMP) dan Sekolah Menengah Atas (SMA). Pada yayasan yang menaungi SMP dan SMAinilah penelitian tepatnya dilakukan. Pondok pesantren tersebut terdapat beberapa santri dan guru yang merupakan pemilih muda dan tersebar di beberapa komplek atau asrama. Kebanyakan pemuda yang ada di sana adalah siswa Sekolah Menengah Atas (SMA) dan mahasiswa di berbagai Perguruan Tinggi (PT) di Yogyakarta. Siswa dan mahasiswa yang sekaligus santri tersebut, menjadi kajian yang menarik untuk diteliti (i-pesantren.com 6 Maret 2015).

Demokrasi dipahami sebagai sebuah ruang lingkup yang sangat luas. Apapun bentuknya, fenomena demokrasi sangat menarik 
Bagus Anwar HidaYatulloh, Sudjito, dan Agus Pramusinto -- Ketahanan Politik Wilayah Pondok Pesantren Dalam Pemilihan Umum 2014 (Studi Terhadap Pemuda Di Yayasan Pondok Pesantren Ali Maksum, Krapyak Kulon, Desa Panggungharjo, Kecamatan Sewon, Kabupaten Bantul, Daerah Istimewa Yogyakarta)

untuk dibicarakan. Apalagi jika dikaitkan dengan kenyataan, bahwa negara Indonesia merupakan negara yang masih menjadikan proses demokratisasi sebagai sebuah tumpuan. Secara substansial, demokrasi tidak akan berjalan dengan efektif tanpa berkembangnya pengorganisasian internal partai, lembagalembaga pemerintahan, maupun perkumpulanperkumpulan masyarakat (Thalhah, 2009:413). Demokrasi yang kuat bersumber pada kehendak rakyat dan bertujuan untuk mencapai kebaikan atau kemaslahatan bersama. Oleh karena itu, demokrasi mesti berkaitan dengan persoalan perwakilan kehendak rakyat itu (Mas'oed, 1999: 6).

Demokrasi mengemukakan bahwa ketika menjalankan pemerintahan secara demokratik terdapat prinsip-prinsip yang harus diperhatikan. Moh Mahfud MD mengemukakan prinsip-prinsip bahwa rakyat harus berpartisipasi dalam pembuatan keputusan, jika rakyat tidak berpartisipasi maka pemerintah tidak boleh membuat kebijakan yang bertentangan dengan kebijakan rakyat, rakyat mempunyai kedudukan yang sama di muka hukum (equality before the law), pendapatan negara harus didistribusikan secara adil bagi seluruh warga negara, semua rakyat harus diberi kesempatan yang sama dalam memperoleh pendidikan, harus ada kebebasan untuk mengemukakan pendapat pendapat termasuk kebebasan pers dan kebebasan untuk berkumpul dan beragama, rakyat harus mendapatkan informasi seluasluasnya, mengindahkan fatsoen atau tata krama politik, harus ada kebebasan individu, semangat kerja sama dan ada hak untuk protes (Mahmuzar, 2010:25)

Pada Era Reformasi, telah terjadi penyelenggaraan pemilihan umum dalam 4 kali pemilu yaitu pemilu tahun 1999, 2004, 2009 dan 2014. Pada keempat pemilu tersebut jumlah partai politik mengalami pasang surut. Pada pemilu tahun 2014 diikuti oleh 15 Partai Politik baik nasional maupun lokal yang memiliki karakter ideologi. Pada Pemilu 2014 masyarakat semakin matang dalam berpolitik, pendidikan politik yang selama ini berlangsung menjadikanya matang sehingga harapan Indonesia ke depan sudah terbentuk (Indonesiaweb.com, 15 April 2015).

Dalam latar belakang ini menimbulkan pertanyaan mengenai bagaimana implikasi ketahanan politik wilayah pondok pesantren dalam pemilihan umum 2014? Dengan latar belakang tersebut, jurnal penelitian ini mengambil judul Implikasi Ketahanan Politik Wilayah Pondok Pesantren Dalam Pemilihan Umum 2014. Jenis penelitian yang digunakan dalam penelitian ini adalah penelitian kualitatif dengan jenis penelitian deskriptif yang memberikan gambaran mengenai berbagai fenomena, menjelaskan hubungan, mendapatkan makna dan implikasi dari suatu masalah. Penelitian kualitatif adalah prosedur penelitian yang menghasilkan data deskriptif berupa kata-kata tertulis atau lisan dari orang-orang dan perilaku yang diamati (Moleong, 2000: 3). Sebagai penunjang data, peneliti menambahkan metode penelitian deskriptif pendekatan kuantitatif sederhana sebagai tambahan data. Pendekatan deskriptif kuantitatif ini digunakan untuk melihat partisipasi yang bersifat personal masing-masing dengan menggunakan skala Guttman.

Studi ini menarik untuk dikaji sebab partisipasi pemuda dalam kontek pemilihan umum di beberapa pondok pesantren berbedabeda. Terlebih lagi Pondok Pesanten Krapyak 
ini merupakan pesantren besar yang ada di Daerah Istimewa Yogyakarta dan peneliti lebih mencondongkan penelitian di Pondok Pesantren Ali Maksum yang mengelola lembaga SMP dan SMA, karena di daerah Krapyak sendiri tidak hanya satu yayasan pondok pesantren saja.

\section{PEMBAHASAN}

\section{Teori Partisipasi}

Partisipasi masyarakat adalah keikutsertaan masyarakat dalam proses pengidentifikasian masalah dan potensi yang ada di masyarakat, pemilihan dan pengambilan keputusan tentang alternatif solusi untuk menangani masalah, pelaksanaan upaya mengatasi masalah, dan keterlibatan masyarakat dalam proses mengevaluasi perubahan yang terjadi (Rukminto, 2007:27).

Partisipasi melibatkan lebih banyak mental dan emosi daripada fisik seseorang, sehingga pribadinya diharapkan lebih banyak terlibat dari pada fisiknya sendiri. Partisipasi yang didorong oleh mental dan emosi yang demikian itu, disebut sebagai partisipasi sukarela. Sedangkan partisipasi dengan paksaan disebut mobilisasi. Partisipasi mendorong orang untuk ikut bertanggung jawab di dalam suatu kegiatan, karena apa yang disumbangkannya adalah atas dasar kesukarelaan sehingga timbul rasa bertanggung jawab kepada organisasi, maka partisipasi politik dibagi menjadi dua kategori: Pertama, Partisipasi otonom, yaitu partisipasi politik yang didorong oleh keinginan pelakunya sendiri untuk melakukan tindakan tersebut. Kedua, Partisipasi mobilisasi, yaitu partisipasi politik yang digerakkan atau diinginkan oleh orang lain, bukan karena kesadaran atau keinginan pelakunya sendiri (Sahid, 2011:183).
Teori tersebut di atas merupakan teori yang digunakan sebagai pisau analisis. Tentunya di Pondok Pesantren Ali Maksum menjadi bagian yang tak terlepaskan dari partisipasi otonom maupun mobilisasi. Jika dalam kajian-kajian sebelumnya banyak ditemukan bahwa pondok pesantren lebih banyak menekankan partisipasi mobilisasi, maka dalam penelitian ini pun kajian ini menjadi menarik dikaji, apakah tetap sama yaitu partisipasi mobilisasi ataukah partisipasi otonom.

Menurut pendapat beberapa ahli beberapa faktor yang menyebabkan orang mau atau tidak mau ikut berpartisipasi dalam politik (Mas’oed, 1999: 67) yaitu:

Pertama, status sosial dan ekonomi. Status sosial ialah kedudukan seseorang dalam masyarakat karena keturunan, pendidikan dan pekerjaan. Sedangkan status ekonomi ialah kedudukan seseorang dalam pelapisan masyarakat berdasarkan pemilikan kekayaan. Seseorang yang memiliki status sosial yang tinggi diperkirakan tidak hanya memiliki pengetahuan politik, tetapi juga mempunyai minat dan perhatian pada politik. Status sosial ekonomi para santri di Pondok Pesantren Ali Maksum berasal dari bermacam-macam status sosial dan ekonomi, tetapi rata-rata santri khususnya di SMP dan SMA Ali Maksum orang tuanya termasuk golongan menengah ke atas.

Kedua, situasi. Situasi politik juga dipengaruhi oleh keadaan yang mempengaruhi aktor secara langsung seperti cuaca, keluarga, kehadiran orang lain, keadaan ruang, suasana kelompok, dan ancaman. Dari hasil observasi penelitian menunjukkan bahwa situasi Pondok Pesantren Ali Maksum sangat kental akan politik, terutama di masa pemilu. Situasi di 
Bagus Anwar HidaYatulloh, Sudjito, dan Agus Pramusinto -- Ketahanan Politik Wilayah Pondok Pesantren Dalam Pemilihan Umum 2014 (Studi Terhadap Pemuda Di Yayasan Pondok Pesantren Ali Maksum, Krapyak Kulon, Desa Panggungharjo, Kecamatan Sewon, Kabupaten Bantul, Daerah Istimewa Yogyakarta)

Pondok Pesantren Ali Maksum mempunyai wilayah yang dekat dengan kota dan pedesaan, berada di batas antara Kota Yogyakarta dan Kabupaten Bantul.

Ketiga, afiliasi politik orang tua. Afiliasi berarti tergabung dalam suatu kelompok atau kumpulan. Afiliasi politik dapat dirumuskan sebagai keanggotaan atau kerjasama yang dilakukan individu atau kelompok yang terlibat ke dalam aliran-aliran politik tertentu. Afiliasi politik mendorong tumbuhnya kesadaran dan kedewasaan politik masyarakat untuk menggunakan hak politiknya secara bebas dan bertanggungjawab dalam melakukan berbagai aktifitas politik, seperti ikut dalam partai politik dalam pemerintahan, ikut dalam proses pengambilan dan pelaksanaan keputusan politik. Afiliasi politik orang tua dari para santri di Pondok Pesantren Ali Maksum juga bermacam-macam. Rata-rata mereka mempunyai pandangan politik yang moderat.

Keempat, pengalaman berorganisasi. Organisasi merupakan suatu sistem yang mengatur kehidupan masyarakat atau bisa diartikan sebagai suatu prilaku yang terpola dengan memberikan jabatan pada orang-orang tertentu untuk menjalankan fungsi tertentu demi pencapaian tujuan bersama. Pengalaman organisasi para santri di Pondok Pesantren Ali Maksum lebih tertuju pada organisasi Nahdlatul Ulama (NU).

Kelima, kesadaran politik. Kesadaran akan hak dan kewajiban sebagai warga negara yang menyangkut tentang pengetahuan seseorang tentang lingkungan masyarakat dan politik, dan menyangkut minat dan perhatian seseorang terhadap lingkungan masyarakat dan politik tempat dia hidup. Kesadaran politik para santri Pondok Pesantren Ali Maksum masih terbentur antara kesadaran diri sendiri dengan pengaruh kyai/pengasuh.

Keenam, kepercayaan terhadap pemerintah. Kepercayaan terhadap pemerintah adalah penilaian seseorang terhadap pemerintah apakah ia menilai pemerintah dapat dipercaya dan dapat dipengaruhi atau tidak, baik dalam pembuatan kebijakan-kebijakan atau pelaksanaan pemerintahan. Kepercayaan kepada pemerintah terutama pasca tahun 2012 sampai 2014 menurun dibandingkan dengan tahun-tahun sebelumnya.

Ketujuh, perangsang partisipasi melalui sosialisasi media massa dan diskusi-diskusi informal. Terkait dengan sosialisasi pemilu memang agak kurang diperhatikan dari KPUD sendiri, tetapi untuk media massa dan diskusidiskusi sudah sangat berkembang di wilayah Pondok Pesantren Ali Maksum.

\section{Ketahanan Politik Wilayah}

Ketahanan politik merupakan teori yang dipergunakan dalam menentukan kaitannya atau dampak yang ditimbulkan dari proses pelaksanaan pemilu. Ketahanan politik adalah sebagi kondisi kehidupan politik bangsa yang berisi keuletan, ketangguhan yang mengandung kemampuan mengembangkan kekuatan nasional, dalam menghadapi dan mengatasi segala tantangan, ancaman, hambatan dan gangguan baik yang datang dari dalam maupun dari luar untuk menjamin kelangsungan kehidupan politik bangsa bernegara berdasarkan Pancasila dan UUD 1945 (www.lemhannas.go.id, 15 Juni 2015).

Ketahanan Politik menurut konsepsi tannas, sebagai bentuk dinamika kehidupan politik yang berisi keuletan, ketangguhan dalam menghadapi dan mengatasi tantangan, ancaman, hambatan serta gangguan yang datang dari luar 
maupun dalam secara langsung maupun tidak langsung untuk menjamin kelangsungan hidup politik bangsa dan negara. Ketahanan politik dalam pengertian tersebut mempengaruhi kesadaran sosial politik, disiplin wilayah dan dinamika sosial. Artiya, konsep ketahanan politik dapat dilihat dari 3 aspek utama yakni: (1). Kesadaran sosial politik, (2). Disiplin wilayah serta (3). Dinamika sosial. Dalam penelitian ini, fokus analisis ketahanan politik akan mengacu kepada ketiga dimensi ketahanan politik tersebut (Lemhannas, 1995:71).

\section{Pondok Pesantren}

Teorisasi politik pesantren, secara historis, fungsi dasar pesantren adalah sebagai lembaga pendidikan Islam. Namun demikian, pesantren juga memiliki pengaruh dan peran politik yang penting di tengah masyarakat tradisional (Horikoshi, 1987:66). Oleh sebab itu, pesantren selalu berada dalam pusaran arus tarik-menarik kepentingan politik, sehingga tidak sedikit pesantren yang akhirnya melibatkan diri dalam politik. Tingkat intensitas dan bentuk keterlibatan pesantren dalam politik bisa bermacam-macam, baik secara langsung maupun tidak, sebagaimana pada pelaksanaan momen-momen politik yang penting seperti pemilihan umum (pemilu), pemilihan presiden (pilpres), atau pemilihan umum kepala daerah (pemilukada).

Ketertarikan umat Islam kepada partai politik bukan saja disebabkan oleh kemampuan partai politik memperjuangkan dan membela kepentingan Islam, tetapi lebih karena adanya tipologi umat Islam dalam memandang hubungan politik dengan Islam. Terdapat tiga tipologi dalam berpolitik ketika dihadapkan dengan Islam, yaitu tipologi ideologis, tipologi kharismatik, dan tipologi rasional.
Dalam tipologi ideologis, umat Islam memposisikan berpolitik sama dengan beragama Islam, sehingga semangat pembelaan politik sama dengan semangat membela dan memiliki Islam. Memilih sebuah partai politik sama dengan memilih agama Islam, dan seterusnya ketaatan dalam politik sama dengan ketaatan menjalankan ajaran Islam. Sedangkan tipologi kharismatis mengasumsikan bahwa umat Islam memilih sebuah partai politik mengikuti sikap dan perilaku sesorang yang dikagumi di sekitarnya. Apa yang dikatakan dan dilakukan figur selalu menjadi rujukan masyarakat. Akibat kekaguman yang berlebihan, umat Islam sering tidak mampu bersikap dan berpikir rasional. Dalam tipologi rasional, kemampuan umat Islam dalam memilih partai politik (atau disebut sikap politik) benar-benar didasarkan pada pandangan rasional (Khoiruddin, 2005: 144).

Memilih atau tidak memilih partai politik tertentu dilihat dari kemampuan partai politik menawarkan program yang dapat memperbaiki atau memperjuangkan nasib rakyat. Mayoritas umat Islam saat ini, masih menempati posisi tipologi pertama dan kedua ketimbang tipologi ketiga. Karena itu, ketika umat Islam memandang bahwa berpolitik sama dengan beragama Islam, karakter itu akan mendorong munculnya tokoh-tokoh agama sebagai tokoh politik. Persoalan umat yang bersinggungan dengan kepentingan politik tidak lagi ditangani oleh politisi profesional, tetapi diambil alih oleh kiai dan tokoh-tokoh pesantren yang merasa memiliki pengaruh dan otoritas keagamaan lebih besar atas umat yang dipimpinnya (Ernas dan Ferry, 2010: 203).

Dengan demikian keterlibatan pesantren dalam politik sesungguhnya membuktikan pandangan di atas. Setiap pesantren dan kyai memiliki cara masing-masing sesuai sejarah 
Bagus Anwar HidaYatulloh, Sudjito, dan Agus Pramusinto -- Ketahanan Politik Wilayah Pondok Pesantren Dalam Pemilihan Umum 2014 (Studi Terhadap Pemuda Di Yayasan Pondok Pesantren Ali Maksum, Krapyak Kulon, Desa Panggungharjo, Kecamatan Sewon, Kabupaten Bantul, Daerah Istimewa Yogyakarta)

pesantren, spektrum pengaruh pesantren di tengah masyarakat, potensi peluang politik yang dimiliki, serta seberapa besar tarikan politik eksternal yang mereka alami. Untuk mendapatkan gambaran proses tersebut, bagian berikut akan menjelaskan tentang prosesproses politik yang melibatkan pesantren dengan mengambil penggambaran dari proses politik yang terjadi di Pondok Pesantren Ali Maksum Krapyak Yogyakarta.

\section{Pemilihan Umum}

Pemilihan umum adalah sarana demokrasi untuk membentuk sistem kekuasaan negara yang berkedaulatan rakyat dan permusyawaratan perwakilan. Kekuasaan negara yang lahir dengan pemilihan umum adalah kekuasaan yang lahir dari bawah menurut kehendak rakyat, oleh rakyat dan untuk rakyat. Pemilihan umum bertujuan untuk menegakkan prinsip kedaulatan rakyat. Sistem pemilu di Indonesia mengenal beberapa teori yang telah dipakai yaitu : (1). Sistem perwakilan berimbang (proporsional representation) dalam sistem ini terdapat beberapa sistem lagi yaitu sistem perwakilan berimbang dengan daftar tertutup (closed list system), sistem perwakilan berimbang dengan sistem daftar terbuka (open list system), sistem perwakilan berimbang variasi the single transferable vote, sistem perwakilan berimbang variasi the single nontransferable vote. selanjutnya yang (2). Sistem distrik (Plurality System) (Gaffar, 2004: 26 ).

\section{Ketahanan Politik Wilayah Pondok Pesantren Ali Maksum Terkait Dengan Partisipasi Pemilu 2014}

Ketahanan politik adalah kondisi dinamik kehidupan politik bangsa yang berisi keuletan, ketangguhan yang mengandung kemampuan mengembangkan kekuatan nasional dalam menghadapi tantangan, hambatan serta gangguan yang berasal dari luar dan dari dalam secara langsung maupun tidak langsung untuk menjamin kehidupan politik bangsa dan negara Republik Indonesia berdasarkan Pancasila dan UUD 1945.

Berdasarkan konsep ketahanan politik tersebut dapat diartikan bahwa ketahanan politik wilayah merupakan ketahanan politik pada suatu wilayah atau daerah yang berisi keuletan dan ketangguhan yang mengandung kemampuan untuk mengembangkan kekuatan wilayah dalam menghadapi tantangan, ancaman, hambatan serta gangguan yang datang dari luar wilayah maupun dari dalam wilayah secara langsung maupun tidak langsung untuk menjamin kehidupan berpolitik di wilayah tersebut. Dalam hal ini adalah ketahanan politik di kawasan pondok pesantren.

Seperti yang tertera dalam kerangka pemikiran di awal penelitian ini bahwa ketahanan politik meliputi 3 aspek, yaitu : (1). Kesadaran sosial politik, (2). Disiplin wilayah, dan (3). Dinamika sosial, maka terjadi kesinambungan terkait parisipasi pemuda dalam pemilihan umum 2014 terhadap ketahanan politik pesantren.

\section{Kesadaran Sosial Politik Di Pondok Pesantren Ali Maksum: Antusiasme Pemuda Terhadap Politik dan Pemilu 2014}

Antusiasme pemuda di Pondok Pesantren Ali Maksum terhadap pemilu 2014 dipengaruhi oleh tingkat kepercayaan terhadap politik dan berujung pada pemilihan umum. Implikasi atas kepercayaan mempengaruhi kesadaran sosial politik terutama dalam pemilihan umum. 
Pertama, kepercayaan pemuda terhadap politik menurun jika dibandingkan pemilu 2009. Kepercayaan sangat penting artinya bagi tata kelola pemerintahan yang baik. Kepercayaan adalah suatu hubungan interpersonal dan konsep organisasi yang komplek. Kepercayaan terjadi ketika pihak yang memiliki persepsi tertentu yang menguntungkan satu sama lain yang memungkinkan hubungan untuk mencapai hasil yang diharapkan. Seseorang mempercayai kelompok atau lembaga akan terbebas dari kekhawatiran dan kebutuhan untuk memonitor perilaku pihak lain, sebagian atau seluruhnya. Kepercayaan adalah cara yang efisien untuk menurunkan biaya transaksi dalam hubungan sosial, ekonomi dan politik (Fukuyama, 1995: 80). Jika sudah melek akan politik, maka partisipasi dalam bentuk apapun terutama dalam pemilihan umum akan lebih demokratis. Pilihan dari kesadaran diri sesuai dengan keyakinan. Tidak berlandaskan sesuatu yang bukan dari diri sendiri. Kepercayaan adalah juga jauh lebih dari itu. Ini adalah fondasi dari semua hubungan manusia dan interaksi institusional, dan kepercayaan memainkan peran setiap kali kebijakan baru diumumkan. Kepercayaan (trust), baik dalam bentuk sosial maupun politik adalah sineqna non (syarat mutlak) pemerintahan yang baik. Tata pemerintahan yang baik dan kepercayaan yang saling membutuhkan satu sama lain, kepercayaan menumbuhkan tata pemerintahan yang baik (Ocampo, 2006:56).

Kedua, kepercayaan pemuda terhadap pemilu 2014 mengalami perubahan haluan. Secara teoretis, dari sudut pandang publik, partai politik adalah kanalisasi dari kepentingan masyarakat agar diperjuangkan menjadi kebijakan negara. Karena masyarakat itu bermacam-macam sehingga kepentingannya juga beragam, parpol pun bermacam-macam. Parpollah yang mengetahui seluk-beluk proses perjuangan agar kepentingan masyarakat itu dapat diakomodasi oleh negara atau sistem politik. Parpol berada di tengahtengah antara negara dan masyarakat dan menjadi jembatan di antara keduanya. Negara memerlukan masyarakat agar tahu kebijakan apa yang semestinya dibuat. Masyarakat memerlukan negara agar kepentingannya dapat diakomodasi. Parpol berfungsi membangun dan memperlancar hubungan antara negara dan masyarakat tersebut. Parpol yang sukses adalah partai yang dekat dengan masyarakat sekaligus memiliki kemampuan untuk berada dalam lingkar kekuasaan agar dapat mengarahkan kebijakan negara sesuai kehendak masyarakat. Namun, hal ini belum menjadi realitas di Indonesia. Masyarakat tampak tidak dekat dengan parpol dan cenderung memiliki pandangan negatif. Sebaliknya, parpol sering kali menyalahkan masyarakat ketika mendapati kenyataan persepsi negatif terhadap politisi ataupun institusi partai.

Faktanya, banyak para kontestan harus menghabiskan banyak uang untuk memberikan tarif makanan dan transportasi untuk menghadiri kampanye, biasanya sebesar Rp. 50.000 (setara dengan 5 dolar AS) per orang, karena tidak semua dari mereka melakukannya atas dasar sukarela (Ida, 2014: 4). Persepsi negatif masyarakat ini tampaknya berkorelasi dengan apa yang tergambar dan terlihat oleh masyarakat atas perilaku atau informasi yang sampai kepada mereka tentang parpol dan politisi di dalamnya. Ketika diminta menggambarkan parpol dan politisi, dalam berbagai jajak pendapat tersebut, tiga hal yang paling diingat masyarakat semuanya negatif. 
Bagus Anwar HidaYatulloh, Sudjito, dan Agus Pramusinto -- Ketahanan Politik Wilayah Pondok Pesantren Dalam Pemilihan Umum 2014 (Studi Terhadap Pemuda Di Yayasan Pondok Pesantren Ali Maksum, Krapyak Kulon, Desa Panggungharjo, Kecamatan Sewon, Kabupaten Bantul, Daerah Istimewa Yogyakarta)

Biasanya masyarakat selalu mengemukakan bahwa politisi adalah orang yang hanya peduli pada kepentingan pribadinya, banyak berjanji, tetapi lebih sering tidak menepatinya, dan lebih suka bicara tentang diri mereka. Dengan ingatan negatif seperti ini, tak mengherankan kalau tingkat kepercayaan publik akan selalu rendah terhadap parpol. Ketidaktertarikan ini bukanlah karena masyarakat tidak memiliki informasi. Sebaliknya, makin banyak masyarakat memiliki akses kepada informasi, ada kecenderungan memiliki persepsi makin negatif kepada politik. Misalnya, makin banyak masyarakat mengakses internet, ada kecenderungan makin negatif persepsinya kepada politik dan karena itu makin tidak tertarik pada politik (kompas.com: 2015/04/11).

Seperti yang terjadi di Pondok Pesantren Ali Maksum bahwa ada dua partai yang di kurun waktu setelah pemilu 2009 sampai dengan 2014 yang berperan, yaitu Partai Demokrat dan Partai Kebangkitan Bangsa. Seperti data sebelumnya pada Partai Demokrat pernah dekat dengan masyarakat Pondok Pesantren Ali Maksum khususnya para kyai dan santri-santri yang ada di sana, tetapi dipandang negatif ketika salah satu pimpinan pondok yaitu Anas Urbaningrum bersitegang dengan Partai Demokrat, tetapi sebaliknya dengan Partai Kebangkitan Bangsa yang mengusung silaturahmi kyai kampung yang diselenggarakan di Pondok Pesantren Krapyak, sehingga menjadikan image partai tersebut baik menjelang pemilu 2014.

Ketiga, kontribusi dalam pemilu 2014 mengalami kenaikan. Secara garis besar bahwa kontribusi pemuda dalam pemilu 2014 lewat keikutsertaan dalam pemilu dan pemungutan suara. Secara keseluruhan pemuda di Pondok Pesantren Ali Maksum terdaftar dalam DPT dan menggunakan hak pilihnya. Keikutsertaan dalam kampanye dalam bentuk mobilisasi terstruktur, yaitu acara-acara yang diadakan oleh pihak pondok pesantren. Sedangkan hak pilihnya diberikan kebebasan dalam memilih. Jika membandingkan dengan pilpres tahun 2009 dan 2014 terdapat peningkatan atas

Tabel 1

DPT Pilpres Tahun 2009 Kecamatan di Kota Yogyakarta

\begin{tabular}{clccc}
\hline No & Kecamatan & $\begin{array}{c}\text { Daftar Pemilih } \\
\text { Terdaftar }\end{array}$ & $\begin{array}{c}\text { Pemilih Yang Menggunakan } \\
\text { Hak pilihnya }\end{array}$ & $\begin{array}{c}\text { Pemilih Yang Tidak } \\
\text { Menggunakan Hak Pilihnya }\end{array}$ \\
\hline 1. & Mantrijeron & 28.461 & 20.360 & 8.217 \\
2. & Kraton & 18.428 & 12.512 & 6.014 \\
3. & Mergangsan & 26.952 & 18.724 & 8.321 \\
4. & Pakualaman & 9.934 & 6.566 & 3.466 \\
5. & Gondomanan & 12.988 & 9.145 & 3.887 \\
6. & Ngampilan & 15.659 & 10.717 & 4.989 \\
7. & Wirobrajan & 21.225 & 15.408 & 5.916 \\
8. & Gedongtengen & 17.120 & 11.977 & 5.834 \\
9. & Jetis & 21.728 & 16.215 & 5.715 \\
10. & Tegalrejo & 29.846 & 21.118 & 8.908 \\
11. Danurejan & 17.425 & 12.216 & 5.314 \\
12. & Gondokusuman & 42.371 & 25.321 & 17.366 \\
13. & Umbulharjo & 54.759 & 38.058 & 17.010 \\
14. & Kotagede & 24.435 & 18.332 & 6.215 \\
\hline & Total & $\mathbf{3 4 1 . 9 3 5}$ & $\mathbf{2 3 6 . 6 6 9}$ & $\mathbf{1 0 7 . 1 7 2}$ \\
\hline
\end{tabular}

Sumber: KPU Kota Yogyakarta 
kesadaran pemilih. Hal ini menandakan bahwa partisipasi pemilih di Kecamatan Mantrijeron mengalami peningkatan. Maka dari itu, implikasi dari partisipasi pemilih berdampak pada peningkatan kesadaran pemilu, sehingga ketahanan politik terkait pemilu berjalan dengan baik.

Tabel 1 tampak bahwa pemilih di Kecamatan Mantrijeron yang menggunakan hak pilihnya berjumlah 20.360 pemilih

Tabel 2

Penggunaan Hak Pilih dalam DPT Pilpres 2014

\begin{tabular}{lcc}
\hline \multirow{2}{*}{ Kecamatan } & \multicolumn{2}{c}{ Penggunaan DPT } \\
& Laki-laki & Perempuan \\
\hline Mantrijeron & 10.061 & 11.343 \\
\hline Total & \multicolumn{2}{c}{$\mathbf{2 1 . 4 0 4}$} \\
\hline
\end{tabular}

Sumber: KPU Kota Yogyakarta

Sedangkan penggunaan hak pilih pilpres 2014 di Kecamatan Mantrijeron berjumlah 21.404 pemilih, sehingga bisa dipastikan terdapat implikasi peningkatan partisipasi dari tahun 2009 dan 2014. Dampak dari partisipasi pemilih di Kecamatan Mantrijeron adalah ketahanan atas kesadaran politik dalam pemilu 2014 tergolong baik (tabel 2).

Tabel 3

Jumlah Suara yang Diterima

\begin{tabular}{llc}
\hline No & \multicolumn{1}{c}{$\begin{array}{c}\text { Uraian } \\
\text { Data Penggunaan Surat Suara }\end{array}$} & $\begin{array}{c}\text { Rincian } \\
\text { Kecamatan } \\
\text { Mantrijeron }\end{array}$ \\
\hline 1. & Jumlah surat suara yang diterima & 26.760 \\
2. & $\begin{array}{l}\text { Jumlah surat suara yang } \\
\text { dikembalikan oleh pemilih karena } \\
\text { rusak/keliru coblos }\end{array}$ & 19 \\
3. & $\begin{array}{l}\text { Jumlah surat suara yang tidak } \\
\text { terpakai }\end{array}$ & 5.337 \\
4. & Jumlah surat suara yang digunakan & 21.404 \\
\hline
\end{tabular}

Sumber: KPU Kota Yogyakarta

Secara rinci penggunaan surat suara terdapat dalam tabel 3, bahwa terdapat 26.760 jumlah surat suara yang diterima, 19 jumlah surat suara yang dikembalikan oleh pemilih karena rusak/keliru coblos, 5.337 jumlah surat suara yang tidak terpakai, sehingga 21.404 jumlah surat suara yang digunakan.

Seperti dalam berita yang ada di laman viva.co.id bahwa Ketua Umum PKB Muhaimin Iskandar dan cawapres nomor urut 2 Jusuf Kalla, Jumat 27 Juni 2014, pukul 14.00 WIB dijadwalkan menghadiri konsolidasi kyai kampung dan istighosah di Pondok Pesantren Al-Munawir Krapyak, Kecamatan Sewon, Kabupaten Bantul, DIY. Dalam acara konsolidasi kiai kampung dan istiqosah di Pondok Pesantren Al-Munawir Krapyak dihadiri 1.000 laskar santri serta kyai kampung. Kegiatan ini dalam rangka menindaklanjuti pertemuan kiai se-DIY. Dalam pertemuan tersebut kiai dan ulama diminta mensolidkan barisan kiai NU untuk mendukung Joko Widodo dan Jusuf Kalla (viva.co.id, 25 Juni 2015).

Kemudian pemuda di Pondok Pesantren Ali Maksum juga berpartisipasi dalam acara maulid akbar. Belasan ribu pengunjung memadati komplek Pondok Pesantren Krapyak Yogyakarta, dalam gelaran acara "Maulid Akbar dan Doa Bersama Untuk Bangsa”, Kamis (13/02) malam. Acara rutin tahunan Jam'iyyah Ta'lim wal Mujahadah Jumat Pon (JTMJP) Padang Jagad Pondok Pesantren Al-Munawwir Krapyak kali ini terselenggara berkat kerjasama dengan Polda DIY (POLRI), Korem 072/Pamungkas (TNI), dan Badan Nasional Penanggulangan Terorisme (BNPT). Sesuai dengan tajuk acara tahun ini “Mewujudkan Pemilu Damai dan Menolak Radikalisme Agama”, Komisi Pemilihan Umum (KPU) mendapat giliran untuk memberi sambutan berikutnya. Diwakili Ketua KPU DIY, Hamdan Kurniawan SIP.,MA., yang menyampaikan betapa pentingnya berpartisipasi 
Bagus Anwar HidaYatulloh, Sudjito, dan Agus Pramusinto -- Ketahanan Politik Wilayah Pondok Pesantren Dalam Pemilihan Umum 2014 (Studi Terhadap Pemuda Di Yayasan Pondok Pesantren Ali Maksum, Krapyak Kulon, Desa Panggungharjo, Kecamatan Sewon, Kabupaten Bantul, Daerah Istimewa Yogyakarta)

dalam pesta rakyat yang digelar 9 April 2014. Semua warga negara Indonesia menggunaan hak pilih dengan baik untuk turut mensukseskan pemilu. (Almunawwir.com, 25 Juni 2015).

\section{Disiplin Wilayah Pondok Pesantren Ali Maksum: Kesadaran Pondok Pesantren Sudah Tidak Asing Dengan Politik}

Pemahaman tentang pondok pesantren sebagai lambang pendidikan Islam tradisional dapat dilihat dari berbagai sudut. Berdasarkan tinjauan sosiologis, arah perkembangan pondok pesantren sering kali ditentukan oleh perkembangan masyarakat, bukan hanya oleh pesantren sebagai subkultur yang menyangkut seluk-beluk tradisi dan keyakinan masingmasing anggota masyarakat pesantren. Bagi masyarakat Jawa, pondok pesantren di bawah kepemimpinan seorang kyai dengan segala atributnya menduduki posisi strategis. Pesantren mendapat desakan yang amat besar dan mampu menembus dinding kehidupan masyarakat. Keberadaan dan popularitas pondok pesantren bahkan dimitoskan oleh karisma kyai dengan dukungan para santri yang tersebar di kehidupan masyarakat (Sukamto, 1997:39-40)

Keadaan wilayah Pondok Pesantren Ali Maksum sehari-harinya merupakan kawasan pendidikan Islam. Seperti diuraikan di atas bahwa Pondok Pesantren Ali Maksum adalah pengembangan dari Pondok Pesantren Ali Maksum. Kajian keislaman di kawasan ini sudah tidak diragukan lagi, karena merupakan kawasan pesantren. Wilayah pondok pesantren ini berada pada kawasan batas Kota Yogyakarta, sehingga suasananya pun campuran antara perkotaan dan pedesaan.

Pernyataan tersebut menandakan bahwa wilayah di Pondok Pesantren Ali Maksum merupakan wilayah yang aksesnya mudah, bukan daerah tertinggal. Kemudian dari beberapa observasi yang peneliti teliti, Pondok Pesantren Ali Maksum merupakan pondok yang yang wilayahnya menyatu juga dengan masyarakat, dalam artian samping kanan kiri pondok merupakan pemukiman penduduk langsung, sehingga sehingga hubungan interaksi sosial antara penduduk di daerah Jogokaryan maupun Krapyak dengan santri atau yang tinggal di Pondok Pesantren Ali Maksum sering terjalin, seperti contoh jual beli.

Internal keadaan di pondok pesantren sendiri, dalam hasil penelitian bahwa merupakan pondok pesantren dengan pendidikan formal dan non formal. Pendidikan formal seperti SMP dan SMA, sedangkan non formal berupa pendidikan ala pesantren seperti mengaji dengan metode sorogan dan bandongan. Sistem tersebut merupakan sistem klasik asli pesantren, baik untuk mengkaji ilmu alat seperti nahwu dan shorof serta ilmu fiqh dan akhlak.

Keadaan di pondok pesantren ini, mengajarkan bahwa seorang murid itu harus menghormati seorang guru apalagi kyai, yang tertuang dalam pembelajaran kitab ta'lim muta'alim baik di sekolah maupun di asrama. Hal ini menandakan bahwa ada pembelajaran moral yang kuat antara seorang santri dengan guru/kyai. Bahwa seorang santri yang ada di sana harus selalu menghormati kepada kyai/guru, karena sistem pembelajaran maupun kitab yang diajarkan terdapat juga mengenai adab-adab seorang murid kepada guru, sehingga membuat seorang santri santri itu sangat respect baik dalam etika maupun adab kepada guru.

Tugas santri di pesantren adalah mempelajari materi yang diajarkan oleh kyai, baik yang berupa teks tertulis maupun secara 
lisan yang dianggap lebih penting karena penyampaiannya langsung dari kyai itu sendiri. Selain dari pemberian materi, salah satu yang paling ditanamkan pada setiap santri yaitu sikap hormat, takzim dan kepatuhan mutlak terhadap kyai. Kepatuhan itu diperluas lagi terhadap ulama sebelumnya dan ulama yang mengarang kitab-kitab yang dipelajarinya. Kepatuhan, bagi pengamat luar tampak lebih penting dari penguasaan ilmu, tapi bagi kyai hal itu merupakan bagian integral dari ilmu yang akan dikuasai, untuk pengajaran agama, pesantren memang tidak memberikan hasil yang paling baik melalui pengajaran formal.

Namun pengaruh agamis yang dihasilkan dari lingkungan yang khas, disiplin dalam menegakkan salat dan pelaksanaan kewajiban Islam lainnya, justru yang lebih penting daripada pengajaran formal. Harapan para santri dan orang tua mereka pada pesantren juga tidak untuk menjadi ulama, tetapi bagaimana harus menjadi orang Islam yang baik. Hanya bagi mereka yang ingin menjadi ulama memang harus mengikuti sebagian besar dari kurikulum yang ada (Steenbrink, 1994: 17)

Dengan adanya kesadaran politik sebagaimana diuraikan di atas, maka keadaan di pondok pesantren ketika pemilu dilaksanakan sangat kondusif, baik yang terkait dengan masalah prosedural maupun masalah substansial. Seperti diketahui bahwa dalam demokrasi terdapat dua sifat, yang pertama bersifat prosedural dan yang kedua bersifat substansial. Prosedur adalah mekanisme berisi tata cara yang harus dijalani dalam melaksanakan kegiatan tertentu untuk mencapai tujuan kegiatan tersebut. Sedangkan substansi adalah penyampaian suara rakyat untuk membentuk lembaga perwakilan dan pemerintahan sebagai penyelenggara negara.
Suara rakyat diwujudkan dalam bentuk hak pilih, yaitu hak untuk memilih wakil dari berbagai calon yang ada (Gaffar, 2004:5).

\section{Dinamika Sosial Di Pondok Pesantren Ali Maksum: Pembimbing Asrama Aktor Pendorong Dalam Partisipasi Pemilu 2014}

Aktor pemuda yang mendorong dalam kaitannya dengan partisipasi dalam pemilu 2014 adalah pembimbing asrama, pembimbing yang notabene masih muda tersebut mempunyai peran yang signifikan dalam mendorong partisipasi pemilu, di antaranya yang mengkoordinir segala kegiatan baik saat acara seperti kampanye dalam bentuk doa bersama dan lain-lain serta mendata santri untuk mendapatkan DPT. Selain pembimbing asrama aktor yang mendorong parisipasi adalah pengasuh/kyai, terutama KH. Atabik Ali, karena memang $\mathrm{KH}$. Atabik Ali tersebut merupakan kyai sepuh yang ada memimpin Pondok Pesantren Ali Maksum ini, yang merupakan anak pertama dari almarhum KH. Ali Maksum yang pernah menjabat sebagai rois amm NU.

\section{Faktor Pendorong Dan Kendala Partisipasi Dalam Pemilu 2014}

\section{Faktor Pendorong Partisipasi: Kharisma Pengasuh}

Kyai merupakan elemen yang esensial dari suatu pesantren dengan demikian, maka sudah sewajarnya apabila pertumbuhan suatu pesantren semata-mata bergantung pada kemampuan kyainya (Dhofir, 1982: 55). Kebanyakan kyai beranggapan bahwa suatu pesantren dapat diibaratkan sebagai kerajaan kecil di mana kyai merupakan sumber mutlak dari kekuasaan dan kemenangan (power and authority) dalam kehidupan lingkungan 
Bagus Anwar HidaYatulloh, Sudjito, dan Agus Pramusinto -- Ketahanan Politik Wilayah Pondok Pesantren Dalam Pemilihan Umum 2014 (Studi Terhadap Pemuda Di Yayasan Pondok Pesantren Ali Maksum, Krapyak Kulon, Desa Panggungharjo, Kecamatan Sewon, Kabupaten Bantul, Daerah Istimewa Yogyakarta)

pesantren. Tidak ada seorang santri atau orang lain yang dapat melawan kekuasaan kyai (dalam lingkungan pesantrennya) kecuali kyai lainnya yang lebih besar pengaruhnya. Para santri selalu berharap dan berpikir bahwa kyai yang dianutnya merupakan orang yang percaya penuh kepada dirinya sendiri (selfconfident), baik dalam soal-soal pengetahuan Islam maupun dalam bidang kekuasaan dan manajemen pesantren (Galba, 1995:62).

Politik identitas para ulama terus berubah dan dipengaruhi oleh banyak hal di luar identitas tersebut. Ini juga menegaskan bahwa identitas itu ciptaan dan sekaligus subjektif. Transformasi politik identitas para ulama merupakan cara mereka menampakkan keberadaannya, bahkan sejak masa kemerdekaan 1945 (Winarti: 2014: 1).

\section{Kendala Partisipasi Pemilu: Wilayah Perbatasan Kabupaten dan Kota}

Berpijak pada landasan teori bahwa ada tiga tipologi dalam berpolitik ketika dihadapkan dengan Islam, yaitu tipologi ideologis, tipologi kharismatik, dan tipologi rasional.Sedangkan pemuda yang ada di Pondok pesantren ini lebih cenderung pada partisipasi dengan tipologi kharismatik yang mengasumsikan bahwa memilih sebuah partai politik mengikuti sikap dan perilaku seorang yang dikagumi di sekitarnya dalam hal ini adalah pengasuh pondok pesantren. Hasil penelitian menunjukkan bahwa pemuda yang ada di Pondok Pesantren Ali Maksum ini, ikut berpartisipasi baik dalam hal kontribusi keikutsertaan dalam kampanye dan pemungutan suara lebih condong dipengaruhi oleh faktor kharismatik seorang pengasuh, sehingga kualitas partisipasinya masih cenderung ke tipologi tingkat kedua yaitu kharismatik.
Kendala dalam partisipasi pemilu di pondok pesantren ini, berkaitan dengan penempatan dafar pemilih tetap (DPT) yang tidak singkron dengan wilayahnya. Seharusnya untuk asrama putri mengikuti daftar pemilih Kabupaten Bantul tetapi dimasukkan di Kota Yogyakarta. terdapat pula sebagian pemuda juga memiliki dua daftar pemilih, yaitu pemilih di wilayah Pondok Pesantren Ali Maksum dan di daerah asal pemuda. Akses dengan lingkungan luar pesantren menjadi kendala partisipasi politik pemuda. Baik partisipasi dalam bentuk kampanye pengetahuan sosial di luar pondok pesantren serta perkembangan politik di luar media. Dari hasil observasi peneliti di Pondok Pesantren Ali Maksum, bahwa terdapat aturan pondok yang hanya membolehkan santri-santri untuk ke luar sekedar membeli makan dan jajan di jam-jam tertentu, menjadikan satu point bahwa ada kendala untuk mengakses di lingkungan luar wilayah pesantren.

Memperhatikan penjelasan panjang tersebut di atas dapat dikatakan bahwa ketahanan politik wilayah telah tercipta dengan cukup baik (positif) di Pondok Pesantren Ali Maksum. Hal tersebut disebabkan oleh adanya partisipasi pemuda di Pondok Pesantren Ali Maksum tersebut, sebagaimana ditunjukkan adanya keuletan dan ketangguhan pemuda dalam menanggapi pemilu 2014.

\section{SIMPULAN}

Berdasar atas pembahasan yang dipaparkan, penelitian ini dapat ditarik simpulan sebagai berikut:

Pertama, ketahanan politik wilayah dalam aspek kesadaran sosial politik di Pondok Pesantren Ali Maksum, dipengaruhi oleh faktor eksternal dan internal dari partisipasi pemuda dalam pemilu 2014 aktif. Faktor 
internalnya adalah kontribusi terhadap pemilu lewat keikutsertaan dalam kampanye dan pemungutan suara. Secara keseluruhan pemuda di Pondok Pesantren Ali Maksum terdaftar dalam DPT dan menggunakan hak pilihnya. Keikutsertaan dalam kampanye dalam bentuk mobilisasi terstruktur, yaitu acara-acara yang diadakan oleh pihak pondok pesantren. Sedangkan hak pilihnya diberikan kebebasan dalam memilih.

Kedua, ketahanan politik wilayah dalam aspek disiplin wilayah di Pondok Pesantren Ali Maksum, ditunjukkan oleh adanya kenyataan, bahwa para pemuda bertempat tinggal di pesantren dengan model campuran, yaitu menggabungkan modernitas dengan model pendidikan tradisional, sehingga cara pandang terhadap pemilu pun lebih baik dari pada pondok pesantren dengan model pendidikan masih murni tradisional. Akibatnya, tingkat ketahanan terhadap disiplin wilayah Pondok Pesantren Ali Maksum tergolong baik. Pondok Pesantren Ali Maksum adalah lembaga pendidikan dan sosial, bukan lembaga politik, tetapi dalam perkembangannya afiliasi politik di wilayah pesantren ini semakin menguat, akibat peran pesantren terhadap politik yang dipelopori oleh pengasuh dan kyai. Hal ini menjadikan ranah disiplin wilayah pondok pesantren sebagai lembaga pendidikan agak terganggu, sehingga berdampak pada kualitas partisipasi pemuda di pondok pesantren ini. Keadaan wilayah pondok pesantren ini berada pada kawasan batas Kota Yogyakarta, sehingga suasananya pun campuran antara perkotaan dan pedesaan. Tugas santri di pesantren adalah mempelajari materi yang diajarkan oleh kyai, baik yang berupa teks tertulis maupun secara lisan yang dianggap lebih penting karena penyampaiannya langsung dari kyai itu sendiri.
Selain dari pemberian materi, salah satu yang paling ditanamkan pada setiap santri yaitu sikap hormat, takzim dan kepatuhan mutlak terhadap kyai. Kepatuhan itu diperluas lagi terhadap ulama sebelumnya dan ulama yang mengarang kitab-kitab yang dipelajarinya.

Ketiga, ketahanan politik wilayah dalam aspek dinamika sosial di Pondok Pesantren Ali Maksum, lebih ditekankan pada aktor-aktor yang mendorong, sehingga partisipasi pemuda berimplikasi terhadap peran seorang leader yang menggerakkan anggotanya untuk turut serta dalam berkontribusi di dalam suatu kegiatan. Hal ini merupakan dinamika sosial yang terjadi akibat dari partisipasi para pembimbing di Pondok Pesantren Ali Maksum, yaitu para aktor pemuda yang mempunyai peran cukup signifikan dalam mendorong partisipasi pemilu di pondok pesantren. Para pembimbing mengkoordinir segala kegiatan baik saat acara seperti kampanye dalam bentuk doa bersama dan lain-lain serta mendata santri untuk mendapatkan DPT. Lebih dari itu terdapat juga yang mendorong partisipasi, yaitu para pengasuh/kyai, terutama KH. Atabik Ali, yang merupakan kyai sepuh yang ada memimpin Pondok Pesantren Ali Maksum ini. KH. Atabik Ali tersebut merupakan anak pertama dari almarhum KH. Ali Maksum yang pernah menjabat sebagai rois amm NU.

\section{DAFTAR PUSTAKA}

Ahmadi, Willy, 2010, Kisah Perjuangan K.H Ali Maksum dalam Tubuh NU 1981-1989, dalam Skripsi Fakultas Adab dan Humaniora, UIN Syarif Hidayatulloh, Jakarta.

Dhofir, Zamarkhasyari., 1982. Tradisi Pesantren: Studi Tentang Pandangan Hidup Kyai , Jakarta: LP3ES.

Ernas, Saidin dan Ferry Muhammadsyah Siregar, 2010, Dampak Keterlibatan 
Bagus Anwar HidaYatulloh, Sudjito, dan Agus Pramusinto -- Ketahanan Politik Wilayah Pondok Pesantren Dalam Pemilihan Umum 2014 (Studi Terhadap Pemuda Di Yayasan Pondok Pesantren Ali Maksum, Krapyak Kulon, Desa Panggungharjo, Kecamatan Sewon, Kabupaten Bantul, Daerah Istimewa Yogyakarta)

Pesantren dalam Politik: Studi Kasus

Pesantren di Yogyakarta dalam JurnalKontekstualita, Vol. 25, No. 2.

Fukuyama, F., 1995. The Social Witnes and The Creations Of Prosperity, New York: Free Press.

Gaffar, Afan., 2004, Politik Indonesia Transisi Menuju Demokrasi, Yogyakarta: Pustaka Pelajar.

Galba, Sindu, 1995. Pesantren Sebagai Wadah Komunikasi, Jakarta: Rineka Cipta, 1995

Horikoshi, Hiroko., 1987, Kiai dan Perubahan Sosial, Jakarta: LP3S,.

Ida, Laode., 2014. Election And Political Evil Ambition In Indonesia's Reformasi Era. International Journal of Politics and Good Governance, Volume 5, No. 5.4 Quarter IV.

Khoirudin., 2005. Politik Kiai, Yogyakarta: Averroes Press.

Lemhannas, 1995,KetahananNasional, Jakarta: PT. IsmoyojatiManunggal.

Mahmuzar, 2010, Sistem Pemerintahan di Indonesia (Menurut UUD 1945 Sebelum dan Sesudah Amandemen), Bandung: Nusa Media.

Mas’oed, Mochtar, 1999, Negara, Kapital dan Demokrasi, cetakan kedua, Pustaka Pelajar Yogyakarta.

Moleong, Lexy. J., 2000, Metodologi Penelitian Kualitatif, Bandung: PT Remaja Rosdakarya,.

Ocampo., (2006). Congratulatory Message; The Regional Forum of Reinventing Goverment in Asia Seoul, Korea

Rukminto Adi, Isbandi., 2007. Perencanaan Partisipatoris Berbasis Aset Komunitas: dari Pemikiran Menuju Penerapan, Depok: FISIP IU Press.
Sahid, Komarudin, 2011. Memahami Sosiologi Politik. Bogor: Penerbit Ghalia Indonesia. Steenbrink, Karel A., 1994, Pesantren Madrasah Sekolah: Pendidikan Islam dalam Kurun Modern, Jakarta: LP3ES.

Sukamto., 1997.”Kepemimpinan dan Struktur Kekuasaan Kyai”, Prisma, XXVI, AprilMei.

Thalhah, HM., 2009, Teori Demokrasi dalam Wacana Ketatanegaraan Perspektif Pemikiran Hans Kelsen, dalam Jurnal Hukum no. 3 vol. 16 Juli.

Winarti, Leni ., 2014. The Political Identity Of Ulama In The 2014 Indonesian Presidential Election, Al-Jāmi 'ah Journal of Islamic Studies, Vol. 52, No. 2.

\section{Internet}

http://i-pesantren.com/id/13/sekolahmenengah-pertama

http://www.almunawwir.com/2014/02/maulidakbar-krapyak-nasionalisme-dan.html http://indonesia-web.blogspot. com/2013/02/2014-perang-ideologi-atau perang.html

http://politik.news.viva.co.id/news/ $\mathrm{read} / 516505 / \mathrm{cak}-\mathrm{imin}-\mathrm{dan}-\mathrm{kalla}-$ kampanye-di-yogyakarta

http://nasional.kompas.com/ read/2015/04/11/15150041/ ParpoldanPersepsiPublik http://krapyak.org/pendidikan/ http://m.inilah.com/news/detail/1965046/ anas-sby-perseteruan-politik-simbolik http://www.lemhannas.go.id/portal/ daftar-artikel/1630-implementasikonsepsi-ketahanan-nasional-danperkembangannya.html 